\title{
Odpowiedzialność materialna ministrów na Litwie
}

\author{
Haroldas Šinkūnas \\ Uniwersytet Wileński, Wydział Prawa \\ Katedra Prawa Publicznego
}

\section{Wstęp}

Kwestie odpowiedzialności materialnej ministrów - członków Rządu Republiki Litewskiej za rzekomo spowodowane szkody w trakcie kierowania ministerstwem niejednokrotnie znajdowały się $\mathrm{w}$ centrum uwagi litewskich mediów i opinii publicznej. Ogromny oddźwięk wywołała sprawa zwolnienia w 2009 r. dyrektora Krajowego Urzędu Pracy, gdy wspomniany dyrektor, nie akceptując podjętej przez ministra zabezpieczenia społecznego i pracy decyzji o jego usunięciu ze stanowiska, zwrócił się do sądu z wnioskiem, w którym zakwestionował legalność zwolnienia. Po rozpoznaniu tej sprawy sądy w $2011 \mathrm{r}$. uznały, że jego usunięcie ze stanowiska dyrektora Urzędu Pracy miało charakter bezprawny, przywróciły go na stanowisko dyrektora i zasądziły od ministerstwa na jego korzyść odszkodowanie w wysokości 377 tys. litów ${ }^{1} \mathrm{z}$ tytułu szkody wyrządzonej bezprawnymi działaniami. Wbrew pojawiającym się od razu po rozstrzygnięciu tej sprawy apelom, nowo powołany minister zabezpieczenia społecznego i pracy zrezygnował ze składania w sądzie wniosku o zrekompensowanie szkody powstałej w wyniku podjętej przez poprzednika decyzji, która przez sąd została uznana za bezprawną, stojąc na stanowisku, że szanse na wygraną w sądzie byłyby nikłe, raczej o wiele bardziej prawdopodobne byłoby spowodowanie jeszcze większych strat dla państwa.

Szeroki rozgłos zyskała również historia zwolnienia dyrektora Departamentu Służby Państwowej przy Ministerstwie Spraw Wewnętrznych przez ministra tego resortu. Po rozpoznaniu sprawy o odwołanie ze stanowiska dyrektora departamentu, sądy uznały zarządzenie ministra $\mathrm{w}$ sprawie zwolnienia dyrektora departamentu za bezprawne, przywróciły zwolnionego urzędnika na stanowisko i zasądziły od ministerstwa na jego korzyść odszkodowanie w wysokości 16 tys. euro. Po zapadnięciu powyższego wyroku Prokuratura Generalna złożyła wniosek

1 Po przeliczeniu na euro według ówczesnego kursu walutowego ta kwota wynosi ok. 110 tys. euro. 
o zrekompensowanie szkody majątkowej poniesionej przez Ministerstwo Spraw Wewnętrznych. Okręgowy Sąd Administracyjny w Wilnie po rozpatrzeniu skargi prokuratury orzekł o zaspokojeniu roszczenia w części ${ }^{2}$, zobowiązując byłego ministra do wynagrodzenia szkody materialnej, która powstała w wyniku jego bezprawnych działań. Zdaniem sędzi, która wydała wyrok, na Litwie „ta sprawa faktycznie ma charakter precedensowy, gdyż sąd zasądził od tak wysokiej rangi urzędnika pokrycie strat materialnych poniesionych przez państwo"3.

Oprócz powyższych historii w mediach krajowych nagłaśniane są również inne przypadki dotyczące szkody wyrządzonej państwu w wyniku podjętych przez ministrów lub kierowników urzędów centralnych decyzji, które przez sąd zostały uznane za bezprawne. Wspomniane sprawy wywołują nie tylko otwartą reakcję polityków, lecz także stają się przedmiotem kontroli Najwyższego Urzędu Kontroli Państwowej4, który twierdzi, że szkoda wyrządzona państwu bezprawnymi decyzjami ma być zrekompensowana przez urzędników państwowych, w tym ministrów, którzy zadecydowali o podjęciu takich decyzji. W raporcie z audytu instytucji publicznych przeprowadzonym przez Najwyższy Urząd Kontroli Państwowej w 2016 r. stwierdza się, że

zrekompensować szkodę z reguły powinna ta osoba, która doprowadziła do jej powstania, bądź osoba ponosząca odpowiedzialność za jej działania. [...] Państwo, po wypłaceniu odszkodowania za szkodę wyrządzoną przez inne osoby, nabywa prawo do żądania od osób, które są odpowiedzialne za spowodowanie wspomnianej szkody, zwrotu tego, co za nich zostało wypłacone (czyli nabywa prawo regresu) . $^{5}$

2 Prokuratura Generalna wnioskowała o zasądzenie od byłego ministra spraw wewnętrznych na rzecz Ministerstwa Spraw Wewnętrznych odszkodowania w wysokości 61805 euro. Okręgowy Sąd Administracyjny w Wilnie w wyroku orzekł, że były minister spraw wewnętrznych ma wypłacić na rzecz Ministerstwa Spraw Wewnętrznych odszkodowanie w wysokości 15907 euro. Do częściowego zasądzenia roszczenia doszło m.in. dlatego, że Okręgowy Sąd Administracyjny w Wilnie nie stwierdzit, by bezprawne działania byłego ministra miały charakter umyślny. Od wspomnianego wyroku Okręgowego Sądu Administracyjnego w Wilnie wniesiono apelację do Naczelnego Sądu Administracyjnego Litwy, który zawiesił postępowanie apelacyjne i zwrócił się do Sądu Konstytucyjnego z wnioskiem o zbadanie kwestii możliwości stosowania wobec ministrów odpowiedzialności materialnej. Sąd Konstytucyjny rozpoznat wniosek Naczelnego Sądu Administracyjnego Litwy i na jego podstawie 8 marca 2018 r. wydał wyrok. Po wydaniu przez Sąd Konstytucyjny interpretacji Naczelny Sąd Administracyjny Litwy wznowił postępowanie administracyjne, jednak wyrok w tej sprawie dotychczas nie zapadt.

3 R. Palaitis będzie musiat wypłacić dla MSW kwotę ponad 15 tys. euro, https://www.delfi. It/news/daily/lithuania/r-palaitis-vrm-tures-atlyginti-per-15-tukst-euru.d?id=69597758 (dostęp: 15.06.2018).

4 Zgodnie z art. 134 ust. 1 Konstytucji Republiki Litewskiej Najwyższy Urząd Kontroli Państwowej sprawuje kontrolę nad prawidłowością zarządzania i zgodnością z prawem wykorzystywania majątku narodowego, a także nad wykonywaniem budżetu państwa.

5 Raport Najwyższego Urzędu Kontroli Państwowej z 19 września 2016 r. nr VA-P-40-1-12 w sprawie zabezpieczenia środków budżetowych w związku z wypłatą odszkodowania za 
Swoje stanowisko Najwyższy Urząd Kontroli Państwowej opiera m.in. na rozwijanej przez Sąd Konstytucyjny Republiki Litewskiej (dalej: Sąd Konstytucyjny, Sąd) oficjalnej doktrynie konstytucyjnej, mówiącej że

w myśl Konstytucji ustawodawca w trakcie stanowienia aktów prawnych ma obowiązek ustanowienia takiej regulacji prawnej, która umożliwia funkcjonariuszom publicznym, którzy sprawują funkcje władzy państwowej, i wszystkim osobom, które podejmują ważne dla społeczeństwa i państwa decyzje, realizowanie swoich uprawnień w sposób poprawny, niepowodujący przenikania się interesów publicznych i prywatnych, niepowodujący powstawania przesłanek prawnych umożliwiających funkcjonariuszom publicznym, którzy sprawują funkcje władzy państwowej, i wszystkim osobom, które podejmują ważne dla społeczeństwa i państwa decyzje, przekładanie interesu własnego lub grupowego nad dobro Narodu lub Państwa Litewskiego w trakcie wykonywania czynności służbowych, poza tym niepozwalający na nadużywanie swego statusu, bliskich osób lub innych osób w celu osiągnięcia korzyści osobistych; taka regulacja ma służyć zapewnieniu skutecznej kontroli sprawdzającej, w jakim stopniu funkcjonariusze publiczni, którzy sprawują funkcje władzy państwowej i wszystkie osoby, które podejmują ważne dla społeczeństwa i państwa decyzje, przestrzegają powyższych wymogów; w przypadku ich nieprzestrzegania przez ww. funkcjonariuszy publicznych i inne osoby wspomniana regulacja ma zapewnić pociągnięcie ich do odpowiedzialności konstytucyjnej lub ustawowej ${ }^{6}$.

W kontekście omawianego tematu szczególnie aktualny i ważny wydaje się wyrok Sądu Konstytucyjnego z 8 marca 2018 r. ${ }^{7}$, wydany po rozpoznaniu sprawy zainicjowanej przez Naczelny Sąd Administracyjny Litwy, dotyczącej zgodności z Konstytucją Republiki Litewskiej (dalej: Konstytucja) ustawy o Rządzie Republiki Litewskiej, w której nie została określona bezpośrednia odpowiedzialność materialna ministra za szkodę materialną, która została wyrządzona instytucjom państwowym lub samorządowym w wyniku bezprawnych zawinionych czynów w trakcie kierowania wewnętrzną administracją ministerialną, inter alia stosowania kar służbowych.

Celem niniejszego opracowania jest krytyczna ocena zawartych w wyroku Sądu Konstytucyjnego z 8 marca 2018 r. argumentów dotyczących odpowiedzialności materialnej ministrów.

stratę wyrządzoną przez inne osoby w przypadkach, o których mowa w ustawach, https:// www.vkontrole.It/audito_ataskaitos.aspx?tipas=2 (dostęp: 15.06.2018).

6 Wyrok Sądu Konstytucyjnego Republiki Litewskiej z 1 lipca 2004 r, „Valstybės žinios” z 2004 r., nr 105, poz. 3894.

7 Wyrok Sądu Konstytucyjnego Republiki Litewskiej z 8 marca 2018 r., TAR, 2018.03.08, nr 3692. 


\section{Wątpliwości dotyczące konstytucyjności regulacji prawnej określającej odpowiedzialność materialną ministrów}

Odpowiedzialność materialna ministrów za bezpośrednią materialną szkodę, która została wyrządzona bezprawnym zawinionym czynem, nie została uregolowana wprost (eksplicytnie) ani w ustawie o Rządzie ${ }^{8}$, ani w ustawie o służbie państwowej ${ }^{9}$, ani w ustawie o odszkodowaniu za straty powstałe w wyniku bezprawnych działań instytucji państwowych i reprezentowaniu państwa i Rządu Republiki Litewskiej ${ }^{10}$ (dalej: ustawa o odszkodowaniu), ani też w innych ustawach.

Sprawy związane $\mathrm{z}$ organizacją i trybem pracy Rządu ${ }^{11}$, w tym sprawy odpowiedzialności oraz sprawozdawczości ministrów, są uregulowane w Konstytucji i ustawie o Rządzie, w której m.in. stwierdza się, że: 1) Rząd ponosi solidarną odpowiedzialność przed Sejmem za swą ogólną działalność ${ }^{12}$, on co najmniej raz w roku w Sejmie przedstawia roczne sprawozdanie ze swojej działalności (art. 5 ust. 1); 2) na żądanie Sejmu Rząd lub poszczególni ministrowie przedstawiają w Sejmie sprawozdanie ze swojej działalności (art. 5 ust. 2); 3) ministrowie ponoszą odpowiedzialność przed Sejmem, Prezydentem Republiki, a bezpośrednio podlegają Prezesowi Rady Ministrów (art. 5 ust. 3) ${ }^{13}$; 4) Prezes Rady Ministrów i ministrowie nie mogą być pociągnięci do odpowiedzialności karnej ani aresztowani, nie może też być w żaden inny sposób ograniczana ich wolność bez uprzedniej zgody Sejmu, a w okresie między sesjami Sejmu - bez uprzedniej zgody Prezydenta Republiki (art. 12) ${ }^{14}$. Zatem w ustawie o Rządzie została określona odpowiedzialność polityczna ministrów i specjalny tryb pociągnięcia ich do odpowiedzialności karnej lub aresztowania, albo ograniczenia ich wolności w inny sposób. Z drugiej strony, ustawa ta nie ustanawia reżimu ich odpowiedzialności materialnej za bezpośrednią szkodę materialną, która została wyrządzona instytucjom lub urzędom państwowym w wyniku bezprawnego zawinionego czynu.

8 Ustawa o Rządzie Republiki Litewskiej, „Valstybės žinios” z 1994 r., nr 43, poz. 772.

9 Ustawa o służbie państwowej Republiki Litewskiej, „Valstybės žinios” z 1999 r., nr 66, poz. 2130.

10 Ustawa o odszkodowaniu za straty powstałe wskutek bezprawnych działań instytucji państwowych i reprezentowaniu państwa i Rządu Republiki Litewskiej, „Valstybės žinios” z 2002 r., nr 56, poz. 2228.

11 Terminem „Rząd” określa się na Litwie organ odpowiadający polskiej „Radzie Ministrów”, z tego względu wyraz ten będzie zapisywany wielką literą.

12 Ten przepis jest analogiczny jak w art. 96 ust. 1 Konstytucji.

13 Ten przepis jest analogiczny jak w art. 96 ust. 2 Konstytucji.

14 Ten przepis jest analogiczny jak w art. 100 Konstytucji. 
Szczególne znaczenie ma fakt, że w ustawie o Rządzie zostały zawarte przepisy o odpowiedzialności materialnej ponoszonej przez inne osoby - kierowników urzędów centralnych i urzędników urzędów centralnych - stwierdzające, że wobec nich odpowiedzialność materialna jest stosowana na podstawie przepisów ustawy o służbie państwowej.

Ustawa o służbie państwowej określa warunki odpowiedzialności materialnej urzędników służby państwowej, tryb postępowania odszkodowawczego i prawo do regresu (roszczenia zwrotnego) przysługujące instytucjom państwowym oraz samorządowym względem urzędników państwowych, którzy doprowadzili do powstania szkody. Co prawda, w art. 4 tej ustawy mówi się, że jej przepisy nie mają zastosowania do polityków państwowych, w tym do ministrów, jako że ministrowie posiadają status polityka państwowego ${ }^{15}$.

W myśl art. 1 ust. 1 ustawy o odszkodowaniu jej przepisy mają zastosowanie w następujących przypadkach: 1) odszkodowania za niesłuszne skazanie, za niesłuszny areszt prewencyjny (pozbawienie wolności), za niesłuszne zatrzymanie, za niesłuszne stosowanie procesowych środków przymusu, za niesłuszne wymierzenie administracyjnej kary aresztu; 2) wykonywania decyzji Europejskiego Trybunału Praw Człowieka oraz Komitetu Praw Człowieka ONZ i innych międzynarodowych organów, których jurysdykcja lub uprawnienia do orzekania w sprawach związanych z naruszeniem praw osób, należących do jurysdykcji Republiki Litewskiej, są uznawane przez Republikę Litewską. Ponadto w art. 1 ust. 1 niniejszej ustawy stwierdza się, że celem ustawy jest m.in. ustanowienie przez państwo trybu stosowania prawa regresu (roszczenia zwrotnego) względem osoby, która wyrządziła szkodę, czyli określenie zasad proceduralnych w zakresie egzekwowania prawa regresu. W art. 5 ust. 1 tej ustawy expressis verbis stwierdza się, że państwo nabywa prawo regresu po dokonaniu wypłaty odszkodowania za szkodę, która została wyrządzona celowymi działaniami (aktami) funkcjonariuszy organów śledczych, funkcjonariuszy prokuratury lub uszędników sądowych, celowymi działaniami (aktami) sędziów i zawinionymi działaniami (aktami) innych funkcjonariuszy organów władzy, urzędników państwowych lub innych pracowników. Politycy państwowi (w tym ministrowie) w ustawie o odszkodowaniu nie zostali wymienieni wprost, można więc wyciągnąć wniosek, że jej przepisy mają zastosowanie wyłącznie w sprawach o odszkodowanie za szkodę lub w sprawach o rekompensatę strat spowodowanych bezpośrednimi działaniami (aktami) podmiotów, o których mowa w przepisach niniejszej ustawy; z drugiej strony, przepisy tej ustawy nie regulują odpowiedzialności materialnej ministrów w przypadku nieprzestrzegania przez nich wymagań prawnych lub w przypadku nienależytego wykonywania przez nich obowiązków w ramach posiadanych kompetencji.

15 Akceptując takie stanowisko, Sąd Konstytucyjny w wyroku z 8 marca 2018 r. podkreślit, że w celu rozstrzygania kwestii odpowiedzialności materialnej ministrów nie może być stosowana regulacja prawna zawarta w ustawie o służbie państwowej. 
À propos, posłanka na Sejm, reprezentująca Sejm przed Sądem Konstytucyjnym w sprawie zgodności z Konstytucją ustawy o Rządzie, w której wyrok wydano 8 marca 2018 r., również stała na stanowisku, że przepisy ustawy o odszkodowaniu nie powinny mieć zastosowania do ministrów. Poza tym zwróciła ona uwagę na fakt, iż prawo regresu (roszczenia zwrotnego) zostało przyznane państwu, aby umożliwić odzyskanie kosztów z tytułu odszkodowania, które zostało wypłacone za szkodę spowodowaną umyślnymi działaniami (aktami) funkcjonariuszy organów śledczych, funkcjonariuszy prokuratury lub urzędników sądowych, celowymi działaniami (aktami) sędziów bądź zawinionymi działaniami (aktami) innych funkcjonariuszy organów władzy, urzędników państwowych lub innych pracowników. Ta regulacja ma związek z wymaganiami kwalifikacyjnymi, które muszą spełniać osoby, by móc wykonywać czynności służbowe. Tymczasem wymagania kwalifikacyjne dla ministra jako polityka państwowego nie zostały określone. Poza tym projekty decyzji podejmowanych przez ministra zazwyczaj są opracowywane przez pracowników ministerstwa, którzy wykazują się odpowiednimi kompetencjami z zakresu tworzenia prawnych i umotywowanych rozwiązań, i którzy mają zapewnić, by podejmowane przez ministra decyzje były zgodne z prawem.

Takie (nie)uregulowanie odpowiedzialności materialnej ministrów w aktach prawnych posłużyło za podstawę dla Naczelnego Sądu Administracyjnego Litwy, by podnieść sprawę luki w prawie, tj. podważyć nie tyle ustanowioną regulację prawną, co fakt, że w obowiązujących aktach prawnych brak przepisów, których ustanowienie nakazuje Konstytucja.

Ponadto warto zauważyć, że Naczelny Sąd Administracyjny Litwy swoje wątpliwości co do konstytucyjności wspomnianej regulacji prawnej opierał m.in. na właściwościach cechujących odpowiedzialność ministrów. Z jednej strony, ministrowie ponoszą odpowiedzialność polityczną, która oznacza, że za swoją działalność odpowiadają przed Sejmem, Prezydentem Republiki i bezpośrednio podlegają Prezesowi Rady Ministrów. Z drugiej strony, określone w art. 98 Konstytucji kompetencje ministra $\mathrm{w}$ zakresie kierowania ministerstwem suponują osobistą odpowiedzialność ministra za działalność ministerstwa, dlatego powinna być prawnie uregulowana także odpowiedzialność materialna ministra za szkodę, która powstała w wyniku jego bezprawnych działań w trakcie kierowania ministerstwem. Ponadto Sąd Konstytucyjny miał wątpliwość, czy z braku odpowiedzialności materialnej ministra nie jest naruszona konstytucyjna zasada równości, o której mowa w art. 29 Konstytucji, tj. czy minister w sposób nieuprawniony został pominięty w wykazie osób, które pełnią funkcje kierowników instytucji i urzędów państwowych, chociaż między ministrem a ww. kierownikami nie istnieją różnice o takim charakterze i w takim zakresie, by odmienne traktowanie tych osób było obiektywnie uzasadnione. 


\section{Sąd Konstytucyjny: ministrowie ponoszą osobistą odpowiedzialność za działania, w wyniku których powstała szkoda}

Po rozpoznaniu sprawy o zgodności z Konstytucją ustawy o Rządzie Sąd Konstytucyjny w wyroku z 8 marca 2018 r. orzekł, że: a) ministrowie ponoszą osobistą odpowiedzialność za wszystkie swoje czynności wykonywane w trakcie kierowania ministerstwem; b) ministrowie, którzy swoim bezprawnym działaniem (bezczynnością) doprowadzili do powstania szkody, powinni za to odpowiadać w określonym trybie; c) państwo - po naprawieniu szkody wyrządzonej bezprawnymi działaniami (bezczynnością) ministrów - powinno otrzymać rekompensatę z tytułu poniesionych kosztów (całkowitą lub częściową) od ministrów, którzy w sposób wadliwy zrealizowali swoje uprawnienia. Sąd Konstytucyjny również podkreślił, że w ustawie o Rządzie nie istnieje luka w prawie, bowiem od momentu spełnienia przez państwo obowiązku pokrycia szkody powstałej w wyniku bezprawnych działań ministrów należy stosować przepisy kodeksu cywilnego, m.in. art. 6.280 ust. 1, na mocy których państwo ma prawo do regresu (roszczenia zwrotnego) względem osoby, która wyrządziła szkodę, czyli ministra, a także należy stosować przepisy określające szczegółowy tryb stosowania ustawy o odszkodowaniu. Uwzględniając powyższe, Sąd Konstytucyjny wyjaśnił, iż bez względu na to, że ustawa o Rządzie nie zawiera przepisów ustanawiających odpowiedzialność materialną ministrów za szkodę, która została wyrządzona instytucjom lub urzędom państwowym w wyniku bezprawnego zawinionego czynu, taka odpowiedzialność ministrów jest ustanowiona w ustawie o odszkodowaniu, dlatego ustawa o Rządzie nie jest sprzeczna z Konstytucją.

\section{Argumentacja Sądu Konstytucyjnego}

Wyrok Sądu Konstytucyjnego z 8 marca 2018 r. w sprawie odpowiedzialności materialnej ministra został oparty na trzech grupach materiałów źródłowych, czyli na oficjalnej doktrynie konstytucyjnej rozwijanej przez Sąd Konstytucyjny, na raporcie Komisji Weneckiej oraz na interpretacji prawa powszechnego i orzecznictwie Naczelnego Sądu Administracyjnego Litwy. 


\subsection{Doktryna Sądu Konstytucyjnego}

Za każdym razem $\mathrm{w}$ trakcie rozpatrywania sprawy z zakresu sądownictwa konstytucyjnego Sąd Konstytucyjny, dokonując interpretacji treści przepisów i zasad mających istotne znaczenie dla sprawy, szeroko referuje oficjalną doktrynę prawa konstytucyjnego oraz kieruje się jej założeniami. W aspekcie granic odpowiedzialności ministrów istotne znaczenie ma art. 98 ust. 1 Konstytucji, w którym stwierdza się: „Minister kieruje ministerstwem, rozstrzyga kwestie należące do zakresu działania ministerstwa oraz wykonuje czynności przewidziane przez ustawę". Oficjalna doktryna konstytucyjna wyjaśniająca przepis art. 98 ust. 1 Konstytucji nie jest rozwinięta, w związku z tym interpretując treść powyższego przepisu w wyroku z 8 marca 2018 r., Sąd w zasadzie opierał się tylko na jednym orzeczeniu, wydanym 23 listopada 1999 r. ${ }^{16} \mathrm{~W}$ nim Sąd Konstytucyjny m.in. stwierdził, że treść przepisu „minister kieruje ministerstwem” składa się z następujących elementów: zgodnie $\mathrm{z}$ trybem określonym $\mathrm{w}$ ustawach i innych aktach prawnych ministrowi przysługują uprawnienia $\mathrm{z}$ zakresu doboru pracowników ministerstwa, ich zatrudniania $\mathrm{w}$ ministerstwie oraz zwalniania $\mathrm{z}$ pracy; ministrowi przysługują uprawnienia z zakresu organizacji pracy kadry ministerialnej, by zapewnić realizację określonych w ustawach i innych aktach prawnych funkcji ministerstwa; ministrowi przysługują uprawnienia z zakresu wydawania poleceń służbowych dla wszystkich pracowników ministerstwa, którzy są zobowiązani do ich wykonywania; ministrowi przysługują uprawnienia z zakresu stosowania środków dyscyplinarnych wobec wszystkich pracowników ministerstwa w przypadku, gdy oni nie wykonują swoich obowiązków służbowych lub poleceń ministra bądź wykonują te obowiązki i polecenia w sposób nienależyty, poza tym ministrowi przysługują uprawnienia z zakresu przyznawania nagród dla wszystkich pracowników ministerstwa. W wyroku z 23 listopada 1999 r. Sąd Konstytucyjny także podkreślił, że zakres kompetencji ministra związanych z kierowaniem ministerstwem zakłada osobistą odpowiedzialność ministra za całościową działalność ministerstwa, w tym za działalność gospodarczo-finansową.

Jak widać, w wyroku z 23 listopada 1999 r. Sąd Konstytucyjny nie wypowiedział się o odpowiedzialności materialnej ministrów, a w sprawie odpowiedzialności ministrów w sensie ogólnym ograniczył się do przedstawienia pobieżnych uwag, a zatem ukazując cechy odpowiedzialności ministrów, Sąd Konstytucyjny przede wszystkim opiera się na zasadach konstytucyjnych sformułowanych w dotychczasowym orzecznictwie konstytucyjnym, a mianowicie: na zasadzie odpowiedzialnego zarządzania, która suponuje, że wszystkie instytucje państwowe i urzędnicy powinni wykonywać swoje czynności, kierując się Konstytucją i prawem, a prowadząc działania w najlepiej pojętym interesie Narodu i państwa, muszą w spo-

16 Wyrok Sądu Konstytucyjnego z 23 listopada 1999 r., „Valstybės žinios” z 1999 r., nr 101, poz. 2916. 
sób należyty realizować uprawnienia, które zostały im nadane przez Konstytucję i ustawy; na zasadzie transparentności, która m.in. przewiduje zdawanie relacji z działalności całej wspólnocie oraz ponoszenie odpowiedzialności przez decydentów za podejmowane decyzje i która jest traktowana jako niezbędna przesłanka do zapobiegania nadużyciom władzy; a także na zasadzie państwa prawa, która m.in. określa odpowiedzialność władz wobec społeczeństwa i która jest bardzo szeroko stosowana w orzecznictwie Sądu Konstytucyjnego. Innymi słowy, sformułowane w doktrynie Sądu zasady konstytucyjne są ważną podstawą służącą do wyjaśniania zarówno kwestii odpowiedzialności ministrów w ogóle, jak i kwestii ich odpowiedzialności materialnej w szczególności.

Ponadto należy zauważyć, że z powodu braku jasnych (wyrażonych wprost w tekście Konstytucji) merytorycznych argumentów dotyczących odpowiedzialności materialnej ministrów Sąd Konstytucyjny kieruje się „całościową regulacją prawną zawartą w Konstytucji” oraz logicznymi argumentami uzasadniającymi wykładnię tekstu Konstytucji. Sąd m.in. wskazuje, że w Konstytucji zostały zawarte poniższe przepisy związane z odpowiedzialnością ministrów: po pierwsze, w art. 96 ust. 2 Konstytucji została określona odpowiedzialność polityczna ministrów ponoszona przed Sejmem, Prezydentem Republiki i Prezesem Rady Ministrów za kierowanie powierzonymi im działami administracji państwowej; po drugie, w art. 100 Konstytucji został ustanowiony immunitet chroniący ministrów przed odpowiedzialnością karną lub ograniczaniem wolności. Jednak, jak podkreśla Sąd Konstytucyjny, w Konstytucji nie ma innych przepisów określających wyjątkowy - w porównaniu $\mathrm{z}$ innymi podmiotami - status ministrów. Uwzględniając powyższe, Sąd dochodzi do wniosku, że nie ma podstaw do twierdzenia, iż na mocy Konstytucji wobec ministrów należy stosować inne zasady odpowiedzialności niż wobec innych osób, a ponadto podkreśla, że wykładnia stwierdzająca, jakoby ministrom na mocy Konstytucji musiał przysługiwać również innego rodzaju immunitet chroniący od odpowiedzialności prawnej (z wyłączeniem wskazanego w art. 100 Konstytucji), byłaby niezgodna $z$ innymi konstytucyjnymi przepisami i zasadami oraz suponowałaby udzielenie przywileju zakazanego Konstytucją. Z powyższego wynika, że urzędnicy państwowi, w tym ministrowie, którzy wyrządzili szkody, powinni w określonym trybie odpowiadać za działania, w wyniku których powstała szkoda. Jednak, moim zdaniem, taki dedukcyjny wywód (sylogizm) Sądu Konstytucyjnego nie wydaje się wystarczająco przekonujący - w tym wypadku warto byłoby sięgnąć również po inne metody $\mathrm{z}$ zakresu interpretacji prawa ${ }^{17}$.

Sąd Konstytucyjny podkreśla, że szkodę powstałą w wyniku bezprawnych działań (bezczynności) ministrów powinno pokryć państwo. Po wypłaceniu odszkodowania państwo nabywa prawo regresu (roszczenia zwrotnego) względem oso-

17 À propos, w orzecznictwie Sądu Konstytucyjnego wielokrotnie wypowiadano się o tym, że dokonując wykładni treści przepisów konstytucyjnych, należy stosować różne metody interpretacyjne. 
by, która wyrządziła szkodę, czyli ministra. Gdyby ministrowie, którzy wyrządzili szkodę, nie mieli obowiązku pokrycia strat (w całości lub w części) poniesionych przez państwo, nie można byłoby zapewnić poniesienia odpowiedzialności za swoje czyny przez urzędników państwowych, w tym ministrów, którzy wyrządzili szkody; taki stan spowodowałby podważenie zaufania obywateli do instytucji władzy publicznej i do państwa w ogóle, poza tym byłoby to niezgodne z konstytucyjnymi zasadami odpowiedzialnego rządzenia i rządów prawa.

W sprawie wątpliwości Naczelnego Sądu Administracyjnego Litwy, tj. czy brak odpowiedzialności materialnej ministrów nie skutkuje naruszeniem konstytucyjnej zasady równego traktowania osób, Sąd Konstytucyjny wypowiedział się bardzo lakonicznie, m.in. stwierdzając, że konstytucyjna zasada równego traktowania osób nie wyklucza różnego traktowania osób ze względu na ich status lub sytuację. Adekwatne rozstrzygnięcie $\mathrm{w}$ ustawach dylematów związanych z równością osób nie jest możliwe bez dokonania każdorazowo oceny tego, czy określenie cech charakterystycznych tych osób w regulacji prawnej jest uzasadnione.

\subsection{Założenia raportu Komisji Weneckiej}

Wyrok Sądu Konstytucyjnego z 8 marca 2018 r. opiera się m.in. na raporcie w sprawie związku między odpowiedzialnością polityczną i odpowiedzialnością karną, opracowanym przez Komisję Europejską na rzecz Demokracji przez Prawo (Komisję Wenecką), będącą organem doradczym Rady Europy w kwestiach konstytucjonalizmu, który został przyjęty w dniach 8-9 marca 2013 r. na jej 94 . sesji plenarnej ${ }^{18}$. Mimo że ten raport jest sfokusowany na badaniu odpowiedzialności politycznej i odpowiedzialności karnej ministrów, została w nim przedstawiona definicja prawna pojęcia „odpowiedzialność ministrów”, z jednoczesnym podkreśleniem, że odpowiedzialność karna to jeden z rodzajów odpowiedzialności prawnej. Zatem odpowiedzialność prawna wobec ministrów jest stosowana w przypadkach złamania przez nich prawa i powstania skutków prawnych, za które mogą być stosowane sankcje karne lub inne sankcje (punkt 10). Ponadto ministrowie powinni podlegać prawu, a za jego naruszenie powinni ponosić odpowiedzialność prawną (punkt 13), ministrowie nie są ponad prawem (punkt 80 ), mają być pociągani do odpowiedzialności prawnej, chyba że w szczegółowych zasadach określających ograniczony zakres immunitetu mówi się inaczej (punkt 107). Tak więc w raporcie na temat odpowiedzialności materialnej ministrów za naruszenia prawa, do których dochodzi w wyniku ich bezprawnych działań, niczego nie powiedziano.

Podsumowując założenia sformułowane w raporcie Komisji Weneckiej na temat odpowiedzialności ministrów, Sąd Konstytucyjny wskazał, że ministrowie, którzy

18 Report on Relationship between political and criminal ministerial responsibility. Adopted by the Venice Commission at its $94^{\text {th }}$ Plenary Session (Venice, 8-9 March 2013), https://www.venice. coe.int/webforms/documents/default.aspx?pdffile=CDL-AD(2013)001-e (dostęp: 15.06.2018). 
dopuścili się naruszenia prawa, powinni być pociągnięci do odpowiedzialności prawnej, z wyjątkiem przypadków, gdy w zasadach określających immunitet chroniący ich przed odpowiedzialnością prawną expressis verbis stwierdza się inaczej.

\subsection{Interpretacja prawa powszechnego i przytoczenie argumentów z orzecznictwa Naczelnego Sądu Administracyjnego Litwy}

Jak wspomniano wcześniej, w ustawie o Rządzie nic się nie mówi o możliwości stosowania odpowiedzialności materialnej wobec ministrów, ale w jej tekście wskazano wprost na możliwość stosowania odpowiedzialności materialnej wobec kierowników i urzędników urzędów administracji rządowej. Takie rozwiązanie ustawodawcy rzekomo miałoby oznaczać, że z jego woli została ustanowiona właśnie taka regulacja prawna, w myśl której ministrowie nie mogą (nie powinni) być pociągani do odpowiedzialności materialnej za działania wykonywane $\mathrm{w}$ ramach swoich uprawnień konstytucyjnych. W przeciwnym razie, trzymając się argumentacji logicznej lub metody prowadzącej do ustalenia intencji ustawodawcy, z trudem da się wytłumaczyć, dlaczego w ustawie o Rządzie, która w pierwszej kolejności reguluje gwarancje, granice uprawnień i kompetencji właśnie członków Rządu - Prezesa Rady Ministrów i ministrów - niczego nie powiedziano o odpowiedzialności materialnej członków Rządu, ale wypowiedziano się o odpowiedzialności materialnej kierowników i urzędników urzędów administracji rządowej, znajdujących się w sensie podporządkowania hierarchicznego na niższym szczeblu systemu instytucji władzy państwowej. Argumentację mówiącą o tym, że odpowiedzialność materialna nie powinna być stosowana wobec ministrów, moim zdaniem, wzmacnia również regulacja prawna zawarta w ustawie o Rządzie, która stanowi, że kierownicy i urzędnicy urzędów administracji rządowej ponoszą odpowiedzialność na podstawie przepisów ustawy o służbie państwowej, a jak wspomniano wcześniej, niniejsza ustawa nie ma zastosowania do ministrów.

Mimo że właśnie takie nieustanowienie (nieuregulowanie) odpowiedzialności materialnej ministrów w ustawie o Rządzie wzbudziło wątpliwości Naczelnego Sądu Administracyjnego Litwy co do zgodności tej ustawy z Konstytucją, Sąd Konstytucyjny nie zakwestionował takiej regulacji prawnej, a jedynie wypowiedział się na temat techniki prawodawczej konstatując, że

ustawodawca, zmierzając do zapewnienia jednolitości i koherencji systemu prawa w jak największym stopniu, swobodę regulowania odpowiedzialności członków Rządu (Prezesa Rady Ministrów i ministrów) za szkodę wyrządzoną ich działaniami danej osobie [...] mógłby zrealizować poprzez ustanowienie odpowiedniej regulacji prawnej w specjalnym akcie prawnym dotyczącym działalności Rządu - w ustawie o Rządzie ${ }^{19}$.

19 Wyrok Sądu Konstytucyjnego Republiki Litewskiej z 8 marca 2018 r., TAR, 2018.03.08, nr 3692. 
Wywód, że odpowiedzialność materialna może być i powinna być przypisana ministrom pomimo tego, że w ustawie o Rządzie wcale się o niej nie wspomina, Sąd Konstytucyjny wyprowadził z przepisów zawartych w innych ustawach. Ramy takiej interpretacji narzuca art. 42 ustawy o administracji publicznej ${ }^{20}$, który stanowi, że podmiot administracji publicznej za naruszenie wymagań określonych w niniejszej ustawie ponosi odpowiedzialność w trybie ustawowym, a szkoda majątkowa lub niemajątkowa, która powstała $\mathrm{w}$ wyniku bezprawnych działań podmiotu administracji publicznej, jest wynagradzana zgodnie z trybem określonym w kodeksie cywilnym i innych ustawach. Przepis ten ma istotne znaczenie ze względu na fakt, że podmiotem administracji publicznej może być inter alia również polityk państwowy, w tym minister, co oznacza, że szkoda wyrządzona jego bezprawnymi działaniami musi być zrekompensowana zgodnie z zasadami określonymi w kodeksie cywilnym i w innych ustawach. Uwzględniając ten fakt oraz przepisy art. 6.271 kodeksu cywilnego, Sąd Konstytucyjny podkreślił, że: a) minister należy do grupy podmiotów, z powodu których bezprawnych działań państwo ma obowiązek wypłacenia odszkodowania z tytułu szkody; b) obowiązek wypłacenia przez państwo odszkodowania $\mathrm{z}$ tytułu szkody powstaje bez względu na zawinienie ministra; c) podstawą odpowiedzialności za szkodę jest niedziałanie ministra w sposób, w jaki powinien działać w oparciu o ustawy.

W tym kontekście szczególnie należy zwrócić uwagę na nietypową dla orzecznictwa Sądu Konstytucyjnego praktykę, a mianowicie fakt, że dokonując interpretacji cech odpowiedzialności cywilnej państwa i mówiąc o warunkach stwierdzenia bezprawności działań, Sąd Konstytucyjny przywołuje orzecznictwo innych litewskich sądów, a w omawianym przypadku - orzecznictwo Naczelnego Sądu Administracyjnego Litwy, odnosząc się do dwóch wyroków tego sądu, które zapadły w sprawach administracyjnych.

Należy także zauważyć, że Sąd Konstytucyjny zanegował wcześniej wspomnianą przesłankę mówiącą o tym, że w myśl ustawy o odszkodowaniu odpowiedzialność materialna wobec ministrów nie jest stosowana. Zdaniem Sądu przepis art. 1 ust. 1 ustawy o odszkodowaniu mówiący o tym, że „niniejsza ustawa określa [...] tryb realizacji przez państwo prawa regresu (roszczenia zwrotnego) względem osoby, która wyrządziła szkodę [...]" oraz przepis art. 2 ust. 1 mówiący o tym, że „[...] w budżecie państwa każdego roku należy asygnować środki na odszkodowanie za szkodę, która powstała w wyniku bezprawnych działań funkcjonariusza organów śledczych, prokuratora, sędziego lub sądu [...] bądź w wyniku bezprawnych działań (aktów) innych instytucji władzy państwowej [...]" oznaczają nie tylko określenie ustawowych zasad proceduralnych dla realizacji prawa regresu w przypadku, gdy państwo wypłaciło odszkodowanie, ale również przyznanie w ustawie o odszkodowaniu państwu, które wypłaciło odszkodowanie, uprawnień

20 Ustawa o administracji publicznej Republiki Litewskiej, „Valstybės žinios” z 1999 r., nr 60, poz. 1945. 
do odzyskania w trybie regresowym poniesionych kosztów od funkcjonariusza organów śledczych, prokuratora, sędziego lub sądu, a także od każdego innego podmiotu prawa publicznego, tj. inter alia od ministra, w wyniku którego bezprawnych działań powstała szkoda. Sąd Konstytucyjny podkreślił, że gdyby przepisy ustawy o odszkodowaniu były stosowane wyłącznie w przypadku odszkodowania szkody wyrządzonej działaniami funkcjonariuszy organów śledczych, funkcjonariuszy prokuratury lub urzędników sądowych oraz działaniami sędziów, to „nie miałyby sensu przepisy, o których mowa w art. 5 ust. 1 ustawy o odszkodowaniu, a także inne przepisy niniejszej ustawy regulujące prawo państwa do regresu (roszczenia zwrotnego) względem funkcjonariuszy innych instytucji publicznych, urzędników państwowych lub innych pracowników, którzy tę szkodę wyrządzili”"21.

W tym miejscu dostrzegamy dość dziwną argumentację Sądu Konstytucyjnego. $\mathrm{Z}$ jednej strony fakt, że w ustawie o Rządzie nic się nie mówi na temat odpowiedzialności materialnej ministrów, ale przewiduje się możliwość stosowania takiej odpowiedzialności wobec kierowników i urzędników urzędów administracji rządowej, nie stanowi podstawy do stwierdzenia przez Sąd Konstytucyjny luki w prawie, chociaż Naczelny Sąd Administracyjny Litwy tę regulację podał w wątpliwość. Z drugiej strony, na podstawie analizy przepisów ustawy o odszkodowaniu Sąd stwierdza, że mają one zastosowanie do szerszej grupy podmiotów (w tym ministrów), a nie tylko do funkcjonariuszy organów śledczych, funkcjonariuszy prokuratury lub urzędników sądowych i sędziów, którzy bezprawnymi działaniami wyrządzili szkodę, w przeciwnych razie „nie byłoby sensu” mówić o ,innych funkcjonariuszach publicznych, urzędnikach państwowych lub innych pracownikach", o których mowa w 5 ust. 1 ustawy o odszkodowaniu. To w zasadzie oznacza, że wskazani w ustawie „inni funkcjonariusze lub pracownicy" przez interpretujący tę ustawę Sąd Konstytucyjny byli potraktowani jako przesłanka do tego, by zaliczyć ministrów do grupy tych podmiotów, względem których państwo uzyskuje prawo regresu (roszczenia zwrotnego) w przypadku wypłacenia odszkodowania za szkodę powstałą w wyniku ich bezprawnych działań.

Ponadto, mając na uwadze art. 5 ustawy o odszkodowaniu, Sąd Konstytucyjny wskazał, że nabycie przez państwo prawa regresu (roszczenia zwrotnego) względem podmiotu, który wyrządził szkodę, następuje według poniższego trybu: 1) prawo regresu względem funkcjonariusza organów śledczych, funkcjonariusza prokuratury lub urzędnika sądowego i sędziego przysługuje tylko w przypadku, gdy dochodzi do wyrządzenia szkody na skutek umyślnego działania tych osób; 2) prawo regresu względem urzędnika innych organów władzy, urzędnika państwowego lub innego pracownika przysługuje tylko w przypadku, gdy dochodzi do wyrządzenia szkody na skutek zawinionego - a nie na skutek umyślnego - działania tych osób. Poza tym Sąd wskazał inne warunki realizacji prawa regresu: a) prawo regresu jest realizowane tylko $\mathrm{w}$ drodze postępowania sądowego; b) określone są następujące granice regresu - państwo od osób, które wyrządziły szkodę, może odzyskać kwotę 
nieprzekraczającą dziewięciu ich średnich miesięcznych wynagrodzeń, chyba że inne ustawy stanowią inaczej.

Podsumowując przedstawioną w wyroku Sądu Konstytucyjnego z 8 marca 2018 r. interpretację prawa powszechnego i analizę orzecznictwa Naczelnego Sądu Administracyjnego Litwy, należy odnotować, że poświęcono im bardzo dużo uwagi - rozważania o charakterze interpretacyjnym i analitycznym zajmują ponad 35\% całego tekstu wyroku. Skupienie się na interpretacji prawa powszechnego, a nie na wykładni Konstytucji i analizie oficjalnej doktryny konstytucyjnej wywołuje zdziwienie, tym bardziej że w tej sprawie sądownictwa konstytucyjnego rozpatrywana była ewentualność wystąpienia w ustawie o Rządzie luki prawnej oraz zgodność z Konstytucją takiej regulacji prawnej, a nie kwestia zgodności z ustawami podustawowego aktu prawnego, np. rozporządzenia Rządu. Taki sposób argumentacji zastosowany przez Sąd Konstytucyjny należy oceniać jako zjawisko kontrowersyjne, szczególnie z uwzględnieniem faktu, iż Sąd wielokrotnie podkreślał, że interpretacja konstytucyjnych norm i zasad nie może być oparta na aktach prawnych stanowionych przez ustawodawcę lub innego prawodawcę, gdyż w takim wypadku doszłoby do zaprzeczenia zasady nadrzędności Konstytucji w porządku prawnym ${ }^{22}$.

\section{Podsumowanie}

W wyroku Sądu Konstytucyjnego z 8 marca 2018 r. po raz pierwszy została przedstawiona interpretacja mówiąca o tym, że po pierwsze, minister należy do grupy podmiotów, z powodu których bezprawnych działań państwo ma obowiązek naprawienia szkody; po drugie, obowiązek naprawienia szkody przez państwo powstaje mimo braku zawinienia ze strony ministra, a po trzecie, podstawą odpowiedzialności jest fakt, że minister nie działał w taki sposób, w jaki powinien działać w myśl ustaw.

Po wypłaceniu odszkodowania za szkodę wyrządzoną bezprawnymi działaniami ministra państwo uzyskuje prawo regresu (roszczenia zwrotnego) względem ministra, który wyrządził szkodę. Warunki realizacji prawa regresu (roszczenia zwrotnego) są następujące: po pierwsze, prawo to jest realizowane wyłącznie w drodze postępowania sądowego; po drugie, zostały określone granice regresu - państwo od osób, które wyrządziły szkodę, może dochodzić należności w wysokości nieprzekraczającej kwoty dziewięciu ich średnich miesięcznych wynagrodzeń, jeżeli inne ustawy nie stanowią inaczej.

W ustawie o Rządzie, w której nie została uregulowana odpowiedzialność materialna ministrów, Sąd Konstytucyjny nie dostrzegł wadliwej pod kątem konsty-

22 Wyrok Sądu Konstytucyjnego Republiki Litewskiej z 23 lutego 2011 r., „Valstybės žinios” z 2011 r., nr 24, poz. 1180. 
tucyjnym regulacji prawnej - luki w prawie, stwierdzając, że odpowiedzialność materialna ministrów została określona w ustawie o odszkodowaniu.

Wyrok Sądu Konstytucyjnego z 8 marca 2018 r. oparty jest na analizie trzech rodzajów źródeł: konstytucyjnej doktryny Sądu Konstytucyjnego, raportu Komisji Weneckiej oraz wykładni prawa powszechnego i orzecznictwa Naczelnego Sądu Administracyjnego Litwy.

\section{Santrauka}

\section{Ministrų materialinè atsakomybė Lietuvoje}

Straipsnyje nagrinejjama materialinès atsakomybès taikymo ministrams galimybè, jos taikymo pagrindai ir taisyklès. Kad materialinè atsakomybė ministrams gali būti taikoma vienareikšmiškai 2018 m. kovo 8 d. nutarime konstatavo Konstitucinis Teismas. Vyriausybės ịstatyme, reglamentuojančiame Vyriausybès veiklos organizavimo, ministru atsakomybės ir atskaitomybès klausimus, apie materialinę ministrų atsakomybę nekalbama. Dèl tokio teisinio reguliavimo atitikties Konstitucijai suabejojęs Lietuvos vyriausiasis administracinis teismas kreipèsi ị Konstitucinị Teismą prašydamas išaiškinti, ar šiuo atveju nèra legislatyvinès omisijos, t.y. situacijos, kai galiojančiuose teisės aktuose nèra nustatyta tai, kas pagal Konstituciją turètų būti nustatyta.

Lietuvos vyriausiojo administracinio teismo kreipimosi pagrindu pradètą konstitucinès justicijos bylą išnagrinėjęs Konstitucinis Teismas nurodè, kad a) ministrai asmeniškai atsako už visą savo veiklą vadovaujant ministerijai, b) neteisètais veiksmais (neveikimu) žalą padarę ministrai turi nustatytąja tvarka atsakyti už savo veiksmus, dẻl kurių atsirado žala ir c) valstybė, atlyginusi neteisètais ministro veiksmais (neveikimu) padarytą žalą, turi gauti dèl savo patirtų (visų ar dalies) praradimų atlyginimą iš savo igaliojimus netinkamai igyvendinusių ministrų. Nors Vyriausybės įstatyme materialinė ministrų atsakomybė nèra nustatyta, tačiau legislatyvinès omisijos nèra, nes ministrų neteisètais veiksmais padarytą žalą atlyginusi valstybė igyja regreso (atgręžtinio reikalavimo) teisę i žalą padariusị asmenį, i̊skaitant ir ministrą, pagal Žalos atlyginimo įstatyme nustatyta tvarką.

Konstitucinio Teismo išaiškinimas grindžiamas trejopais šaltiniais: Konstitucinio Teismo formuojama oficialiąja konstitucine doktrina, Venecijos komisijos ataskaita ir ordinarinès teisès interpretacija. Kadangi Konstitucijos tekste ir ligšiolinèje Konstitucinio Teismo jurisprudencijoje nèra tiesioginių argumentų, kurių pagrindu būtų įmanoma patvirtinti materialinės atsakomybès taikymo ministrams galimybę, Konstitucinis Teismas savo poziciją argumentuoja konstituciniais atsakingo valdymo, skaidrumo ir teisinès valstybès principais. Apie galimybę patraukti ministrus materialinèn atsakomybèn nieko nekalbama ir Venecijos komisijos ataskaitoje dèl politinès ir baudžiamosios ministrų atsakomybès santykio, todèl Konstituciniam Teismui tenka remtis šioje ataskaitoje įtvirtintomis bendrojo pobūdžio nuostatomis, kurių esmè ta, kad už padarytus teisès pažeidimus ministrai turi atsakyti. 
Nors Konstitucinio Teismo praktikoje tai yra neịprasta, bet ordinarinei teisei aiškinti Konstitucinio Teismo nutarime yra skirtas didelis demesys - jis sudaro daugiau kaip $35 \%$ viso nutarimo teksto. Šio aiškinimo rezultatas - Konstitucinis Teismas nurode, kad ministras gali būti traukiamas materialinèn atsakomybèn už kaltais, o ne tik tyčiniais veiksmais padarytus teisès pažeidimus. Ministro kaltais neteisètais veiksmais padarytą žalą atlyginusi valstybė igyja regreso teisę, kuri igyvendinama tik teismine tvarka ir pagal kurios maksimali riba - devyni vidutiniai ministro darbo užmokesčiai.

\section{Literatura}

\section{Akty prawne}

Ustawa o Rządzie Republiki Litewskiej, „Valstybès žinios” z 1994 r., nr 43, poz. 772.

Ustawa o administracji publicznej Republiki Litewskiej, „Valstybės žinios” z 1999 r., nr 60, poz. 1945.

Ustawa o służbie państwowej Republiki Litewskiej, „Valstybės žinios” z 1999 r., nr 66, poz. 2130. Ustawa o odszkodowaniu z tytułu strat powstałych wskutek bezprawnych działań instytucji publicznych i reprezentowaniu państwa i Rządu Republiki Litewskiej, „Valstybès žinios” z 2002 r., nr 56, poz. 2228.

Wyrok Sądu Konstytucyjnego Republiki Litewskiej z 23 listopada 1999 r., „Valstybès žinios” z 1999 r., nr 101, poz. 2916.

Wyrok Sądu Konstytucyjnego Republiki Litewskiej z 1 lipca 2004 r., „Valstybės žinios” z 2004 r., nr 105, poz. 3894.

Wyrok Sądu Konstytucyjnego Republiki Litewskiej z 8 marca 2018 r., TAR, 2018.03.08, nr 3692.

Postanowienie Sądu Konstytucyjnego Republiki Litewskiej z 23 lutego 2011 r., „Valstybės žinios” z 2011 r., nr 24, poz. 1180.

Report on Relationship between political and criminal ministerial responsibility. Adopted by the Venice Commission at its $94^{\text {th }}$ Plenary Session (Venice, 8-9 March 2013), https:// www.venice.coe.int/webforms/documents/default.aspx?pdffile=CDL-AD(2013)001-e (dostęp: 15.06.2018).

Raport Najwyższego Urzędu Kontroli Państwowej z 19 września 2016 r. nr VA-P-40-1-12 w sprawie zabezpieczenia środków budżetowych w związku z wypłatą odszkodowania za stratę wyrządzoną przez inne osoby w przypadkach, o których mowa w ustawach, https://www.vkontrole.lt/audito_ataskaitos.aspx?tipas=2 (dostęp: 15.06.2018).

\section{Inne}

R. Palaitis będzie musiał wypłacić dla MSW kwotęponad 15 tysięcy euro, https://www.delfi.lt/ news/daily/lithuania/r-palaitis-vrm-tures-atlyginti-per-15-tukst-euru.d?id=69597758 (dostęp: 15.06.2018). 